\title{
Achieving sustainable development goals from the perspective of solid waste management plans
}

\author{
K. M. Elsheekh ${ }^{1,2^{*}}$ (D, R. R. Kamel ${ }^{2}$, D. M. Elsherif ${ }^{1}$ and A. M. Shalaby ${ }^{2}$
}

\author{
* Correspondence: kareem \\ elsheekh@hbrc.edu.eg \\ ${ }^{1}$ Department of Architecture, \\ Housing and Building National \\ Research Center (HBRC), Giza, Egypt \\ ${ }^{2}$ Department of Architecture, \\ Faculty of Engineering, Cairo \\ University, Giza, Egypt
}

\begin{abstract}
Achieving the Sustainable Development Goals (SDGs) by 2030 ad is one of the challenges and among the cross-cutting issues that countries around the world strive to achieve, despite it is not mandatory, to take control of the various negative environmental, economic, social, and urban impacts that threatened cities, in addition to benefits that are realized from achieving it. The research aims to promote the achievement of Sustainable Development Goals from the perspective of solid waste management (SWM) plans and programs, through analyzing and finding the interrelationship between SWM plans and programs and the related specific targets for each goal, in addition to using experts' questionnaires to conclude the varying degrees of impact of SWM plans and programs at the level of 17 SDGs, which have been classified into groups, according to the most and the least affected by the SWM plans and programs. Where the goals of "sustainable cities and communities" and "good health and well-being" came in the lead of the goals; however, the goals of "quality education" and "peace, justice, and institutions" came in the tail of the goals that are affected by SWM plans and programs, according to the experts' opinion.
\end{abstract}

Keywords: Integrated solid waste management, Sustainable Development Goals, Decentralized solid waste management, Merging informal SWM sector

\section{Introduction}

Rapid growth and urbanization processes in developing countries over the past decades have negatively affected cities, such as high rates of poverty and unemployment; problems related to providing infrastructure and social services, in addition to environmental problems and depletion of local resources; and other negative economic, social, and environmental impact be annexed on cities. Therefore, the need for achieving the Sustainable Development Goals appeared in all countries.

SDGs address not only the measurable changes in the well-being of people, economic development of countries, and better environment on the planet but also the means of how these changes shall be induced, in addition to enabling an environment

(c) The Author(s). 2021 Open Access This article is licensed under a Creative Commons Attribution 4.0 International License, which permits use, sharing, adaptation, distribution and reproduction in any medium or format, as long as you give appropriate credit to the original author(s) and the source, provide a link to the Creative Commons licence, and indicate if changes were made. The images or other third party material in this article are included in the article's Creative Commons licence, unless indicated otherwise in a credit line to the material. If material is not included in the article's Creative Commons licence and your intended use is not permitted by statutory regulation or exceeds the permitted use, you will need to obtain permission directly from the copyright holder. To view a copy of this licence, visit http://creativecommons.org/licenses/by/4.0/. The Creative Commons Public Domain Dedication waiver (http://creativecommons.org/publicdomain/zero/1.0/) applies to the data made available in this article, unless otherwise stated in a credit line to the data. 
of peace and security and rule of law and conditions for inclusion and participation [1]. All sectors of development can contribute to achieving SDGs, and every contribution, small or big, will make an impact on our world. Integrated solid waste management (ISWM) is one of the systems that can contribute to achieving 17 SDGs; it can act as a strong driver for achieving a wide range of specific target of goals, whether directly or indirectly.

\section{Methods}

The research focuses on the role of ISWM in achieving SDGs; it aims to observe the impact of solid waste management plans and programs on achieving the seventeen sustainable development goals and identifying the sustainable development goals that are the most/the least affected by solid waste plans and programs. The methodology of the research is based on two parts, the first part discussing "the concept of integrated solid waste management and "the role of SWM sector in achieving the SDGs" by analyzing the seventeen sustainable development goals from the perspective of solid waste management plans and programs. The second part is arranging the goals from the most affected by solid waste management to the least, depending on structured interviews and experts' questionnaires for a diverse sample of 30 experts in this field from academics, researchers, and employees in local administrations.

The experts' questionnaires were designed by 27 questions distributed into three sections; the first section included 8 questions at the level of "policies and general principles of the system," the second section dealt with 10 questions at the level of "the solid waste management parties," and the third section dealt with 9 questions at the level of "the technical stages solid waste management." All the sections included the seventeen sustainable development goals. By transcribing the experts' answers through 27 questions and by aggregating the number of times each goal was selected during each of the 27 questions and collecting them, it was possible to calculate the number of points collected for each goal through the use of Microsoft Excel. Accordingly, it was possible to arrange the goals from the most affected by solid waste management to the least.

\section{The concept of integrated solid waste management}

ISWM is used to refer to the management of the chain of processes, which starts with discharge/storage and extends through the collection, intermediate, treatment, and final disposal of all waste materials [2]. The core concept of ISWM has been developed out of the experience to address certain common problems with municipal waste management. The international agencies realized that improvements in waste management could not be achieved through a piecemeal approach. An integrated approach was required to reduce the increasing amount of waste that requires the proper collection, treatment, and disposal [3]. This integrated approach tries to take into account all the dimensions that may affect the solid waste management processes, in addition to taking into account all the actors and influencers on the solid waste management processes.

\section{The role of SWM sector in achieving the SDGs}

Considering SDGs, which encompass multiple sectors of urban governance. It can be seen that the interconnectedness and the basic interdependence between it and the solid waste management sector, where environmentally sound and integrated solid 
waste management programs and plans affect the achievement and improvement of many indicators of SDGs, whether that effect is directly or indirectly. "The environmentally sound management of waste touches on many vital aspects of development," says Silpa Caza [4]. The next part deals with how the solid waste management sector affects the achievement of the SDGs, at the level of 17 goals.

\section{Waste pickers and improve poverty rates}

While it is known, millions of people in developing countries earn their living from recycling or reusing waste. Reliable statistical data are difficult, as waste pickers are mobile and their population may fluctuate by seasons. For example, Brazil's official statistical system found over 229,000 people did this work in 2008 [5]. Many developing countries aim to determine the factors for successful informal sector integration in SWM systems to design measures for the integration of the informal workers in formal waste management strategies, which will have an impact on reducing poverty rates within this sector.

\section{Organic waste and food security}

Recycling of organic waste is a real opportunity to provide a large number of organic fertilizers that may improve the quality of crops and raise the rates of agricultural productivity in countries, thus supporting the provision of more safe and nutritious food throughout the year and reducing the proportion of the world population suffering from hunger. Only $13.5 \%$ of the world's waste is recycled, and $5.5 \%$ turns into organic fertilizer [6]. This requires a greater effort to raise those rates and make greater use of them at the level of that goal.

\section{SWM processes and ensuring a healthy life}

The medical waste disposal system in developing countries is often subject to defects and faults. Under the pressure of crowded hospitals, workers make mistakes and get infected in return. Adopting the proper management of medical waste inside the health facilities, by incineration or sterilizing and shredding, can greatly reduce the transmission of infection and the transmission of pathogens.

In addition, garbage collectors are still exposed on a daily and continuous basis to the dangers of disease and infection as a result of improper practices of sorting and recycling this hazardous waste, especially many are pregnant and postpartum women within the garbage collectors communities, and to the dangers of premature death as a result of their abuse of sorting processes in the informal system and dealing with waste directly without taking precautionary measures to prevent the transmission of infection and disease.

Therefore, hepatitis $\mathrm{C}$ virus (HCV) is one of the most common diseases among litter collectors, which leads to their lives at early ages. Figure 1 shows a comparison between the population in Manshiyat Nasser (one of the largest garbage collectors communities in Egypt) and Greater Cairo by age groups. The available data indicate that the age group over 50 years old in Manshiyat Nasser is much lower compared to Greater Cairo, where the percentage in the Nasser facility is $8.4 \%$, while the Cairo governorate is 14.3\%, according to the Central Agency for Public Mobilization and Statistics [7], which 


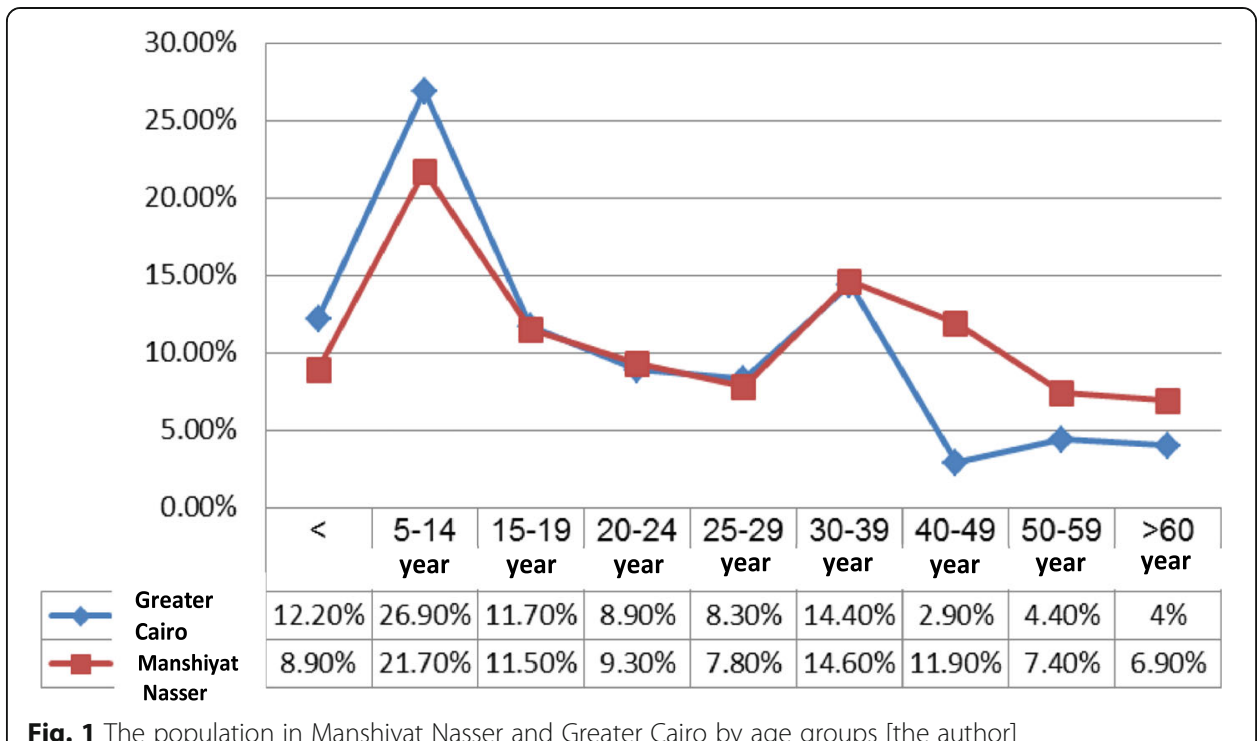

reflects the low average age in the region. This confirms that the proper management of solid waste collection and sorting processes has a great impact on reducing disease rates.

\section{Ensuring quality education for garbage collector communities}

Looking at the garbage collectors' communities in most developing countries, it can be seen the use of children significantly throughout the work system, which increases the cases of illiteracy, and children drop out of education in exchange for the temptations of financial return. As in Manshiyat Nasser, which represents one of the largest garbage collectors' communities in Egypt, statistics indicate that the level of education in it is much lower if compared to Cairo, where the illiteracy rate in Manshiyat Nasser is 52\%, while in Cairo it is 24.2\%, according to the Central Agency for Public Mobilization and Statistics [7]. The illiteracy rate among females in Manshiyat Nasser is 59.6\%, while in Cairo, it reaches $30.6 \%$ for males; the illiteracy rate in Manshiyat Nasser stands at 45.1\%, while in Cairo governorate, it reaches 18.2\% [7]. Figure 2 illustrates an approach between the ratios of the education in Manshiyat Nasser and Greater Cairo.

The previous data can be interpreted as an indication of the increasing rates of dropout from education with the advancement of age in one of the largest garbage collector communities in Egypt as a result of work requirements and the rise of child labor within the profession. The reduction of child labor and the provision of technical and vocational education for them, especially in developing countries, supports enrollment opportunities. In schools and learning for garbage collectors' communities and family members of those in charge of this profession.

\section{Achieve gender equality and empower all women and girls in SWM}

Women and girls are considered one of the main actors in informal SWM as they play a major role in the waste sorting stage, which is one of the most influential stages on health, as most of the sorting processes take place in the informal system inside 


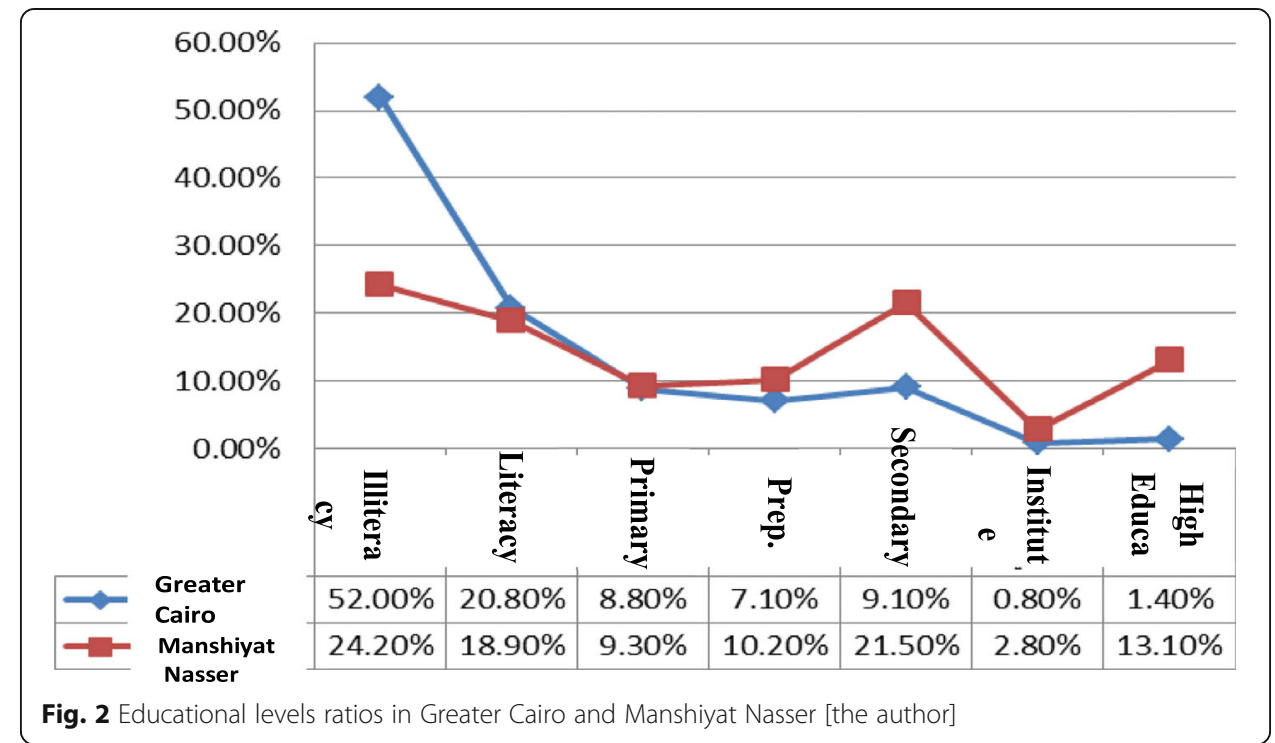

residential spaces and residential streets [8], as shown in Fig. 3 that affects women's health as women spend most of their time inside the home practicing this process, which makes them more vulnerable to serious diseases [9], in addition to the use of young girls in this process as well, which leads to an increase in the educational dropout rate among girls. This confirms the importance of the efforts made by civil organizations in Egypt such as the association for the Protection of the Environment (APE) and Youth Spirit Association (YSA) to spread awareness of the importance of adopting proper practices for sorting solid waste, as well as providing proper job opportunities based on solid waste recycling directed at women and girls and providing medical assistance to women who got infected, in addition to the inclusion of young girls in recycling schools that allow them to practice recycling for a paid fee while ensuring their continuation in the educational system.

\section{Dumping solid waste and provide clean water}

Freshwater sources are exposed to pollution from a wide range of sectors, which threatens human health, as well as wildlife as a whole, and water pollutants include plastic garbage as well as invisible chemicals, in addition to direct discharges of factory waste. It ends up in lakes, rivers, streams, and underground water.
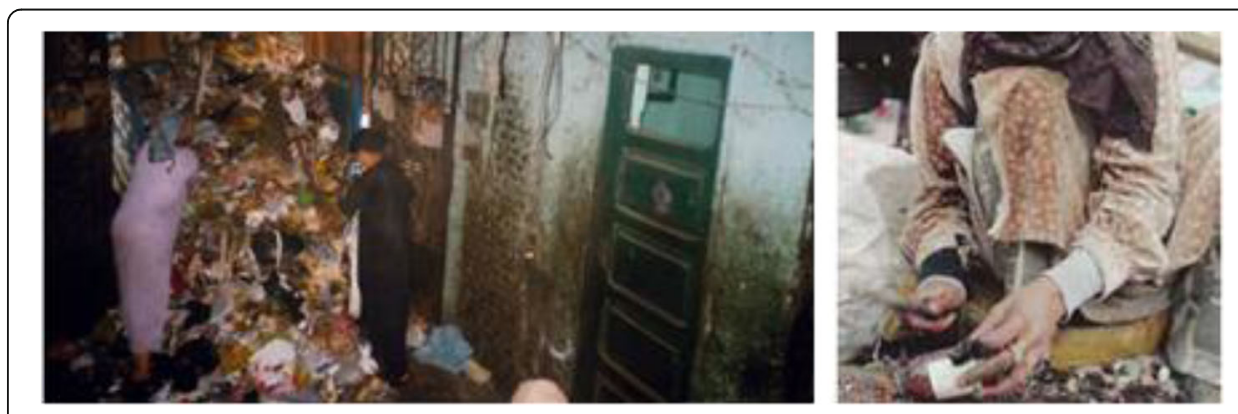

Fig. 3 Women and young girls sorting garbage in Manshiyat Nasser [8] 
One-third of plastic waste ends up in the soil or freshwater. Plastic never degrades, but rather into tiny particles less than $2.5 \mathrm{~mm}$ in size known as nano-plastics, which break down further into nanoparticles (less than $0.1 \mu \mathrm{m}$ in size) and that becomes part of the food chain. Fresh drinking water becomes contaminated with plastic particles, causing various diseases of cancer origin and hormonal disorder s[10]. For sure, reducing pollution caused by dumping hazardous wastes in or near waterways increases the chances of obtaining higher quality water.

\section{Energy recover from solid waste}

The scientific and technical development in dealing with solid waste has led to a review of the tons of waste that the city produces daily, and to look at it as alternative sources of energy. The concept of generating energy from waste is based on chemically treating solid waste to produce energy; waste is currently the third growing renewable energy source worldwide, after solar and wind. It also contributes, with biomass energy, to more than half of the renewable energy used globally [11]. This is what made many countries of the world strive in research and development and devising plans on a large scale to separate garbage and recycle it to convert it into energy.

Now, due to the tremendous development in the science of solid waste management and a large number of specialists in it, more than half of the garbage is incinerated and converted into liquid or gaseous fuels [10].

\section{The informal sector in SWM and decent work for all}

Informal employment remains a major challenge to the goal of providing decent work for all. In the SWM system, the percentage of informal employment is increasing in developing countries, which operates according to a framework that does not guarantee social insurance or safety standards, which requires improving the working conditions of the informal sector in the SWM system by integrating it within the formal framework of the system.

The utilization of the human resources of the informal sector in the SWM system and its accumulated experience in this field according to a framework that guarantees to improve the work environment and provide opportunities for decent work. It can support the promotion of economic growth by increasing the productivity rates of the several SWM sectors, by investing in solid waste recycling technology and maximizing the economic return by saving in the use of raw materials used in industries and replacing them with solid waste materials in different industries. These activities, industries, and small enterprises that are based on recycling operations of solid waste produce great decent job opportunities for the informal sector.

\section{Recycling projects to stimulate industrialization and foster innovation}

Small industries constitute the backbone of industrial development in developing countries [12], with a relatively small amount of investment and a domestic resource base. Small industries generate a great deal of employment and self-employment to which the SWM sector can contribute. Recycling materials is one of the processes that create opportunities for unlimited industries and small projects that stimulate innovation processes in various fields of industry, which depends on the output of sorting solid waste 
from plastic, glass, paper, or cloth and other recyclable materials, in addition to making use of organic waste to create opportunities for small projects that depend on the production of compost from well-separated organic waste. All of that can support growth and innovation processes in manufacturing.

\section{Promoting social and economic inclusion for informal SWM communities}

SWM sector could contribute to achieving economic and social integration within developing countries and reducing inequalities. As it is divided in many developing countries into two main systems, namely the formal and informal systems, each of them affects the economic growth processes to varying degrees. Therefore, the merger between the formal and informal SWM sectors will support the reduction of social and economic inequalities for all.

Many developing countries are making great efforts and multiple attempts and putting forward new policies to support the merging processes between the two systems because of the great economic and social benefits that this merging will bring. Some governments are trying to allay the concerns of the informal sector about bearing new tax and insurance burdens, as they try to add benefits to enjoy health care in addition to implementing appropriate systems of insurances and pensions in exchange for monthly installments. This enhances the ability to reduce social and economic inequalities within communities.

\section{Sustainable SWM enhancing the quality of life}

By looking at the services of SWM, there are two billion people without access to waste collection services globally, and 3 billion people lack controlled waste disposal facilities according to data collected between 2010 and 2018 ad [13]. This leads to a lack of indicators of quality of life for cities and the sustainability of local communities. Therefore, good practices for SWM through waste reduction, reuse, recycling, and exploitation in generating energy or safe disposal of it are an essential element in sustainable city management and improving the quality of life. "It is impossible to create a sustainable, livable city without rational solid waste management. It is no longer about technical solutions only. There are impacts on climate, health, and safety as well as important social considerations," Vasquez stresses [14]. Therefore, there is an urgent need to invest in waste management infrastructure, including the opportunities to convert full landfills into green parks.

\section{SWM and "sustainable consumption and production patterns"}

ISWM contains many concepts related to reducing production and controlling consumption patterns such as moving towards the circular economy model which is based on recycling of materials and converting useful waste into resources. That supports the use of fewer natural resources in manufacturing processes. It can also be said that adopting the concept of extended producer responsibility which requires companies to collect and recycle the waste generated from their products is one of the applications of the green circular economy concepts.

In addition to many practices that are being developed to maximize the benefit from the generated solid waste, such as the MSWM Hierarchy (5Rs), which is considered a 
widely accepted guideline method on what is better for the environment, as it gives top priority to preventing waste generation in the first place then for reuse, recycling, energy recovery, and finally for final disposal. The importance of using the concept of hierarchy for managing solid waste (5Rs) is due to avoiding wasting an important economic value, which is recyclable waste and reducing the rates of environmental pollution.

\section{Solid waste disposal and climate change measures}

Greenhouse gasses such as methane emitted from solid waste are a major factor in air pollution and climate change. Many municipal solid waste (MSW) disposal facilities in developing countries are open dumpsites that contribute to air, water, and soil pollution, as well as greenhouse gas emissions. In 2016, 5\% of global emissions were generated from solid waste [15]. This calls for the need to improve solid waste disposal in most parts of the world, as the safe disposal and the reduction of open burning of garbage are one of the most important climate change-related measures.

According to the statistics issued by the World Bank, the world generates 2.01 billion tons of MSW annually, and at least 33\% of it is not managed in an environmentally safe manner. Without improvements in the SWM sector, emissions related to solid waste are probably to increase to 2.6 billion tons of carbon dioxide equivalent by 2050 ad [16]. Environmentally sound management of solid waste will help reduce the spread of carbon dioxide and other greenhouse gasses in the atmosphere.

\section{SWM and "conserve the oceans, seas, and marine resources"}

The oceans constitute the largest ecosystem on the planet, and they produce about half of the oxygen we breathe and act as a climate regulator, they also absorb heat from the atmosphere and more than a quarter of the carbon dioxide that man makes, and carbon emissions lead to the accumulation of heat in the oceans and to changes in their chemical composition, which increases acidification. Reducing open burning can limit the diffusion of carbon dioxide. On the other hand, plastic waste is one of the biggest threats to the oceans. Global production of plastic reached more than 300 million tons in 2014. Much of this plastic has ended up in the oceans, where plastic waste accounts for $90 \%$ of marine debris, damaging wildlife and harming marine ecosystems [17]. The environmentally sound management of solid waste and its safe disposal, especially plastics, can reduce damage to the oceans.

\section{SWM impact on land ecosystems}

As a result of the rapid urbanization processes and the increase in the population, the solid waste sector is one of the important sectors with a significant impact on the health of ecosystems with their growth rates of waste. One of the aspects of preserving the ecosystems on the earth's surface is the safe disposal of solid waste. and Adopting an integrated and sustainable SWM system, which takes care of reducing the amount of waste from the source according to a set of concepts related to such as the (3Rs), and (5Rs), in addition to the circular economy model, which are all widely accepted approaches and principles for waste management operations. The importance of using these concepts is due to the reduction of waste production, which supports the 
reduction of the need for land utilized for the sanitary burying of waste and using a lower amount of land sustainably and the reduction of the impact on the pollution of soil, water, and air.

\section{Integrated SWM and institutional building strengthening}

Given the ISWM, the institutional framework depends on delegating and distributing responsibilities and functions between central governments and local administrations, in addition to the partnership with the private sector, civil society organizations, and all actors in the system. This ensures that decisions are made in a manner that is responsive, inclusive, participatory, and representative at all levels. Many developing countries have turned to the institutional framework based on the principle of decentralization because of its potential benefits as a result of its application in the processes of integrated solid waste management, such as improving economic efficiency, protecting local interests, enhancing citizen participation, and ensuring the availability of tools and methods to activate transparency and accountability to ensure that the costs of programs and projects are evaluated and then monitor the service delivery process.

\section{Partnerships between different parties and sectors}

The participation of multiple parties in the SWM system is one of the most important points that the system aspires to, as the transformation from the traditional government sector to the government as a partner by adopting multi-lateral partnerships such as the private sector, non-governmental organizations, and the local community has become inevitable and necessary for the success of the SWM system, also establishes partnerships with other sectors such as industry and trade. All of that is a result of the government sector in developing countries' realization of its limited ability alone to meet the increasing demand for SWM services. And its need to benefit from the local and foreign experiences of the private sector, ensure the utilization of the human capital and the accumulated experiences of the informal sector, and the inclusion of the local community in identifying the actual needs and evaluating the services provided to it, all of that to support the improvement of the SWM system's performance. Partnerships with donors also provide opportunities to support the system technically and financially. This supports the achievement of goal 17 by making use of the experiences gained from partnerships and their resource mobilization strategies.

\section{Results and discussion}

In view of the Egyptian case and its similarity with developing countries with regard to the solid waste management systems, the research committed to monitoring the impact of SWM plans and programs in developing countries on achieving SDGs through their specific related targets, as the research limitations.

Through the previous section, it became possible to analyze the possibility of achieving the SDGs from the perspective of SWM plans and programs, as it supports the achievement of a wide range of specific targets set within the 17 SDGs, whether directly or indirectly, starting with the development of the natural and urban environment by improving the quality of life for cities, maintaining the sustainability of local communities, reducing the individual negative environmental impacts of cities, and preserving 
Table 1 The contribution of SWM on SDGs achievement [the author]

\begin{tabular}{|c|c|}
\hline SDGs [18] & Specific target [18] \\
\hline & $\begin{array}{l}\text { 1-1 Eradicate extreme poverty for all } \\
\text { people everywhere }\end{array}$ \\
\hline Goal 1: No poverty & $\begin{array}{l}1-2 \text { Reduce at least by half the proportion } \\
\text { of men, women, and children of all ages } \\
\text { living in poverty }\end{array}$ \\
\hline $2 \pi 600$ & $\begin{array}{l}\text { 2-1 End hunger and ensure access by all } \\
\text { people, in particular, the poor and people } \\
\text { in vulnerable situations, including infants, } \\
\text { to safe, nutritious, and sufficient food all } \\
\text { year round }\end{array}$ \\
\hline
\end{tabular}

2-3 Double the agricultural productivity and incomes of small-scale food producers, in particular, women, indigenous peoples, family farmers

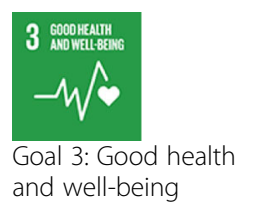

3-1 Reduce the global maternal mortality ratio

3-2 End preventable deaths of newborns and children under 5 years of age, with all countries

3-3 End the epidemics of AIDS and combat hepatitis, water-borne diseases, and other communicable diseases

\section{4 actourtion QIi \\ Goal 4: Quality education}
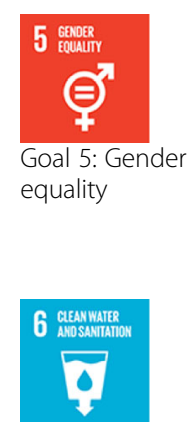

4-1 Ensure that all girls and boys complete free, equitable, and quality primary and secondary education

4-3 Ensure equal access for all women and men to affordable and quality technical, vocational and tertiary education

4-4 Increase the number of youth and adults who have relevant skills, including technical and vocational skills, for employment, decent jobs, and entrepreneurship

5-1 End all forms of discrimination against all women and girls everywhere

5-5 Ensure women's full and effective participation and equal opportunities 5-6 Ensure universal access to reproductive health and reproductive rights as agreed

6-3 Improve water quality by reducing pollution and minimizing the release of hazardous chemicals and materials

\section{SWM plans}

Incorporating the waste pickers and improving their economic conditions has improved poverty rates in the developing world.

Recycling and reuse of solid waste have great potential to create jobs and employment opportunities.

Separating food waste and managing food waste supports providing a measure of food for the poor and vulnerable groups, thus supporting the reduction of hungry populations.

Recycling of organic solid waste produces very good organic fertilizers, increases the chances of doubling agricultural productivity, and enhances the success of agricultural practices for small food producers.

Reducing the sorting processes in the informal system by the denomination of pregnant and postpartum women reduces the maternal mortality rates.

Preventing waste sorting processes in informal solid waste communities that take place indoors and in the streets, reducing the risk of disease exposure for children and infants.

Follow the proper management of medical waste disposal inside the health facilities and use protectors for the hands to prevent injuries, transmission of diseases, and hepatitis during the collection and sorting processes.

Proper handling of solid waste and disposal methods supports a healthy, disease-free environment.

Reducing child labor, as children are part of the informal solid waste system, which increases illiteracy and school dropout rates.

Providing technical and vocational education related to the solid waste management system supports school enrollment and learning opportunities for garbage collectors communities.

Reducing the exploitation of women in the informal system, as they play a major role in the waste sorting stage, making them more vulnerable to diseases.

Providing healthy proper job opportunities based on solid waste recycling directed at women and girls.

Reducing pollution caused by dumping plastic and hazardous wastes into or near waterways. Increases access to higher quality water. 
Table 1 The contribution of SWM on SDGs achievement [the author] (Continued)

\begin{tabular}{l} 
SDGs [18] \\
\hline Goal 7: Affordable \\
and reliable energy \\
8 oceandwoxino \\
Goal 8: Decent \\
work and economic \\
growth
\end{tabular}

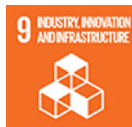

Goal 9: Industry and innovation

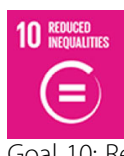

Goal 10: Reduce inequalities

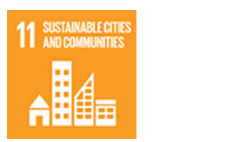

Goal 11: Sustainable cities and communities

12 assousele
Goal 12:
Responsible
consumption and
production

\section{3 alsation

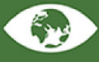 \\ Goal 13: Climate} action

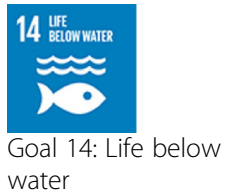

\section{Specific target [18]}

7-1 Ensure universal access to affordable and reliable energy services

7-2 Increase substantially the share of renewable energy in the global energy mix

\section{SWM plans}

The use of solid waste in energy production processes supports the provision of a new and affordable source of energy.

8-1 Sustain per capita economic growth in accordance with national circumstances 8-3 Promote development-oriented policies that support productive activities and decent job creation and encourage the

formalization and growth of micro-, small-, and medium-sized enterprises

8-2 Achieve higher levels of economic productivity through a focus on high valueadded and labor-intensive sectors

9-2 Promote inclusive and sustainable industrialization and significantly raise the industry's share of employment

10-2 Empower and promote the social and economic inclusion of all

11-1 Ensure access for all to adequate, safe, and affordable housing and basic services and upgrade slums

11-6 Reduce the adverse per capita environmental impact of cities, including municipal waste management

11-7 Provide universal access to safe, inclusive, and accessible green and public spaces

12-1 Implement the 10-year framework of programs on sustainable consumption and production

12-2 Achieve the sustainable management and efficient use of natural resources

12-5 Substantially reduce waste generation through prevention, reduction, recycling, and reuse

12-6 Encourage companies to adopt sustainable practices

13-2 Integrate climate change measures into national policies, strategies, and planning

14-1 Prevent and significantly reduce marine pollution of all kinds

14-3 Minimize and address the impacts of ocean acidification
Merging the informal SWM system into the formal system ensures an improvement in the informal work environment and supports economic growth opportunities.

Recycling technology provides more opportunities for higher levels of economic productivity.

Recycling material processes in SWM promotes creating opportunities for unlimited industries and small projects that stimulate innovation processes in various fields of industry

The merge between the formal and informal SWM sectors promotes social and economic inclusion and reduces inequality in developing countries

Integrated and sustainable solid waste management raises the value of indicators of quality of life for cities and maintains the sustainability of local communities.

An integrated solid waste management system reduces the individual negative environmental impacts of cities.

Full landfill sites could be converted into green spaces and public places.

Adopting the green circular economy model ensures the sustainability of patterns.

The efficient orientation of 5Rs greatly reduces waste production.

Adopting the extended producer responsibility policy.

Safe disposal of solid waste and the reduction of garbage open burning and its emitting rates of pollution and greenhouse gasses are among the most important measures related to climate change.

Reducing pollution resulting from dumping solid waste into water bodies, especially plastic, supports the chances of preserving the life of marine organisms underwater.

Environmentally sound management of solid waste reduces the spread of carbon responsible consumption and production 
Table 1 The contribution of SWM on SDGs achievement [the author] (Continued)

\begin{tabular}{|c|c|c|}
\hline SDGs [18] & Specific target [18] & SWM plans \\
\hline & & $\begin{array}{l}\text { dioxide, which absorbs about a quarter of } \\
\text { its emissions by the oceans and increases } \\
\text { their acidification. }\end{array}$ \\
\hline \multirow[t]{2}{*}{$\begin{array}{l}15 \text { uif } \\
\text { Goal 15: Life on } \\
\text { land }\end{array}$} & $\begin{array}{l}\text { 15-1 Ensure the conservation, restoration, } \\
\text { and sustainable use of terrestrial and inland } \\
\text { freshwater ecosystems and their services } \\
15-9 \text { Integrate ecosystem values into } \\
\text { national and local planning and } \\
\text { development processes }\end{array}$ & $\begin{array}{l}\text { The safe disposal of solid waste is one of } \\
\text { the aspects of preserving the ecosystems } \\
\text { on Earth. }\end{array}$ \\
\hline & $\begin{array}{l}\text { 15-3 Restore degraded land and strive to } \\
\text { achieve a land degradation-neutral world }\end{array}$ & $\begin{array}{l}\text { Integrated and sustainable SWM reducing } \\
\text { the amount of waste and landfill areas, that } \\
\text { is reduction of the need for land utilized for } \\
\text { the sanitary burying of waste. }\end{array}$ \\
\hline \multirow{2}{*}{ 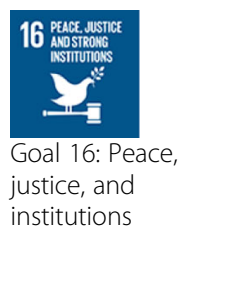 } & $\begin{array}{l}16-6 \text { Develop effective, accountable, and } \\
\text { transparent institutions at all levels }\end{array}$ & \multirow{2}{*}{$\begin{array}{l}\text { SWM within a clear institutional framework } \\
\text { that supports the organization of the } \\
\text { relationship between the central authority } \\
\text { and local administrations; ensure } \\
\text { responsive, inclusive, participatory, and } \\
\text { representative decision-making at all levels; } \\
\text { and provide tools and methods of transpar- } \\
\text { ency, accountability, and monitoring of the } \\
\text { service delivery process. }\end{array}$} \\
\hline & $\begin{array}{l}\text { 16-7 Ensure responsive, inclusive, } \\
\text { participatory, and representative decision- } \\
\text { making at all levels }\end{array}$ & \\
\hline 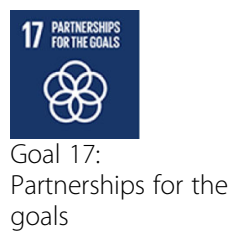 & $\begin{array}{l}\text { 17-17 Encourage and promote effective } \\
\text { public, public-private, and civil society } \\
\text { partnerships }\end{array}$ & $\begin{array}{l}\text { The integrated and sustainable SWM system } \\
\text { depends on the participation of multiple } \\
\text { parties, such as the formal private sector, } \\
\text { the informal sector, the local community, } \\
\text { and donors. This is to support the system } \\
\text { financially and technically. }\end{array}$ \\
\hline
\end{tabular}

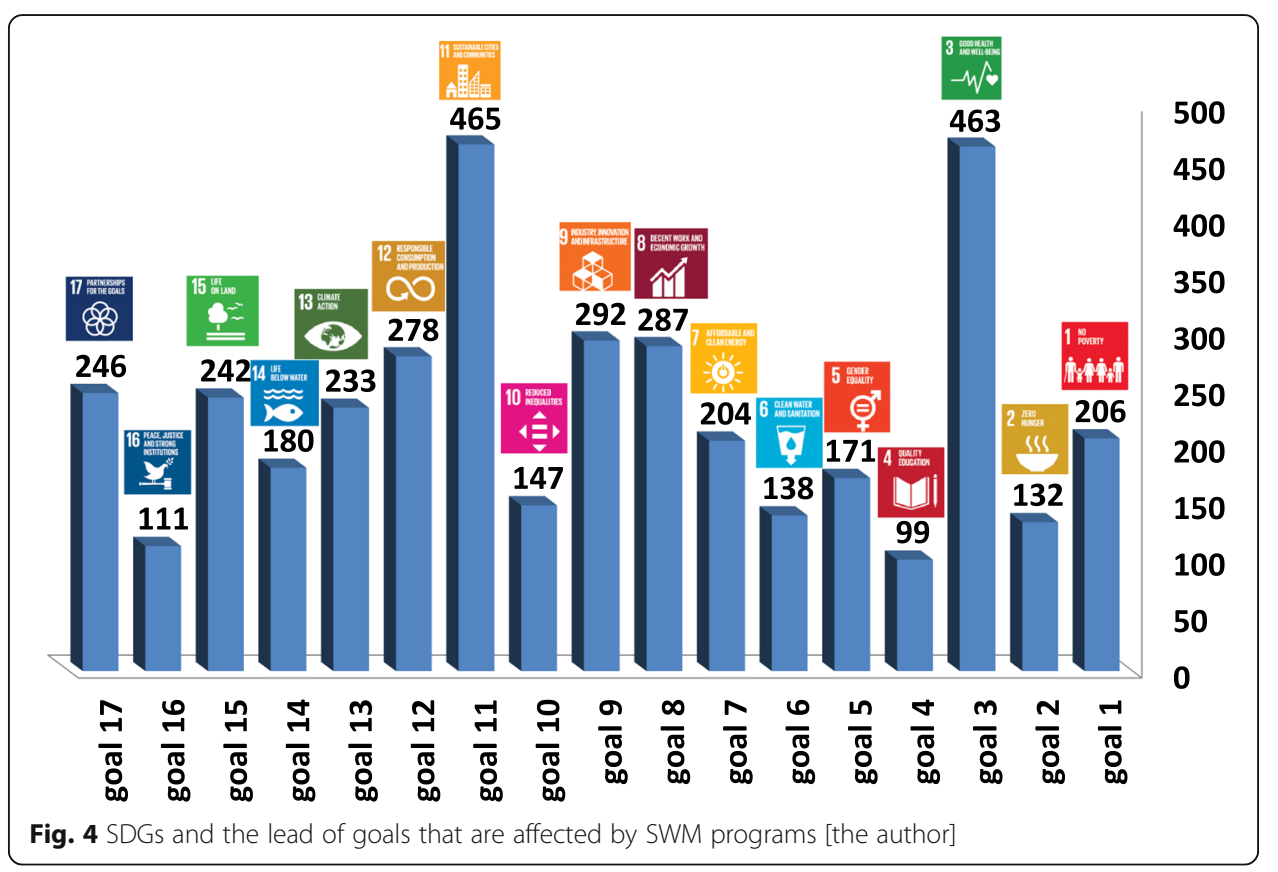


the ecosystems on earth, and its ability to contribute to economic and social development by providing job opportunities. In addition to its support for building transparent institutional frameworks that guarantee partnerships with different sectors and various stakeholders as well. Table 1 deduced the contribution of SWM plans and programs to each of the 17 SDGs.

An expert questionnaire (30 experts) was designed to put the 17 SDGs in the order of the impact of SWM plans and programs on achieving it. The questionnaire included 27 questions distributed into three sections: policies and general principles of the system, the system parties, and the technical stages of the system. Figure 4 shows SDGs and the number of times each goal is chosen as a result of being affected by plans and programs for solid waste management. It is based on analyzing expert answers through 27 questions in the experts' questionnaire.

By transcribing the experts' answers through 27 questions, it is possible to note the following:

- Goal 11: Sustainable cities and communities and goal 3: Good health and well-being goal are in the lead goals that are affected by SWM plans and programs.

- Then, comes the second stage goal 9: Industry and innovation, goal 8: decent work and economic growth, and goal 12: Responsible consumption and production.

- Then, the third stage goal 17: Partnerships for the goals, goal 15: Life on land, and goal 13: Climate action. Then comes the rest of the SDGs.

- Goal 4: Quality education and goal 16: Peace, justice and institutions are representing the least affected goals by the SWM plans and programs, according to the experts' opinion.

\section{Conclusions}

It was clear that there was an impact of solid waste plans and programs on achieving SDGs, in various degrees at the level of 17 SDGs, and the greatest impact appeared in the goals related to improving the quality of life and health in cities, in addition to the goals related to providing decent work for all, supporting industrialization and innovation, and improving production and consumption patterns, as well as addressing climate change, enhancing life on earth and supporting partnerships. While some goals appeared less affected by SWM plans and programs, such as the goal related to quality and equitable education for all and the goal related to establishing institutions subject to the issue. The future direction of research should be focusing on developing a framework for achieving goals 3 and 11 (the most affected by SWM) in Egypt from the perspective of SWM plans and programs.

\footnotetext{
Abbreviations

SWM: Solid waste management; SDGs: Sustainable Development Goals; MSW: Municipal solid waste; 5Rs: Refuse, reduce, reuse, repurpose, recycle; ISWM: Integrated solid waste management; MSWM: Municipal solid waste management

Acknowledgements

Not applicable.

Authors' contributions

KM was a major contributor in writing the manuscript and analyzed and interpreted the experts' questioner data regarding the impact of solid waste management plans and programs on achieving sustainable development goals. DM contributed to identifying the experts to be interviewed. RR, DM, and AM contributed to the review of the experts' questioner and the manuscript. All authors read and approved the final manuscript.
} 


\section{Funding}

The research received no specific grant from any funding agency in the public, commercial, or notfor-profit sectors.

\section{Availability of data and materials}

The datasets generated and analyzed during the current study are available in the Google/forms repository [https:// docs.google.com/forms/d/1eDuL-tDf_xxOAKaDIUKiz8Qji6iGonwbQZHCmCgQc68/edit].

\section{Declarations}

\section{Ethics approval and consent to participate}

The authors declare that the manuscript is our original work. The ideas, views, innovations, and results presented in the above manuscript are totally ours unless otherwise referenced in the text. Works of others necessary for the development of ideas presented in this manuscript are clearly referenced within the text and accurately listed at its end. Also, the authors declare that they consent for publication.

\section{Competing interests}

The authors declare that they have no competing interests.

Received: 16 April 2021 Accepted: 1 July 2021

Published online: 15 September 2021

\section{References}

1. Gurbo M (2017) Why are sustainable development goals important? The institute for development of freedom of information (IDFI) published article, available via: .https://idfi.ge/en/why_does_sdgs_matter. Accessed 1 Mar 2021

2. Starovoytova D (2018), Solid waste management at a university campus (part 1/10): comprehensive-review on legal framework and background to waste management, at a global context, online published paper, J Environ Earth Sci, 8, no.4, p.71. Available via: https://www.researchgate.net/publication/328747778_Legal_Framework_and_Background_to_ Solid_Waste_Management. Accessed 1 Mar 2021

3. Memon MA (2010) Integrated solid waste management based on the 3R approach. J Mater Cycles Waste Manag:7 Available via: https://www.researchgate.net/publication/225707470_Integrated_solid_waste_management_based_on_ the_3R_approach. Accessed 1 Mar 2021

4. Kaza S, Yao LC, Bhada-Tata P, Van Woerden F (2018) What a waste 2.0: a global snapshot of solid waste management to 2050, published book, urban development. World bank, Washington, DC Available via: https://www.worldbank.org/en/ news/immersive-story/2018/09/20/what-a-waste-an-updated-look-into-the-future-of-solid-waste-management. Accessed 1 Mar 2021

5. Dias S (2011) Integrating informal workers into selective waste collection: the case of Belo Horizonte, Brazil, wiego policy brief (urban policies) no. 4

6. The world bank (2018), What a waste: an updated look into the future of solid waste management, how much trash is that?, online article, the world bank, IBRD.IDA, available via: https://www.worldbank.org/en/ news/immersive-story/2018/09/20/what-a-waste-an-updated-look-into-the-future-of-solid-waste-management Accessed 1 Mar 2021

7. Egypt in figures (2013), Central Agency for Public Mobilization and Statistics (CAPMAS), Arab Republic of Egypt, available via: https://www.capmas.gov.eg/. Accessed 1 Mar 2021

8. Flavia C, Joos V (2010) Mokattam world's largest recycling hub, research project, studio-Basel-contemporary city institute, p 136

9. Elsheekh K (2014) The environmental coexistence aspects in functional communities, analytical study of garbage area in Manshiyat Nasser, unpublished master thesis, Faculty of Engineering, Cairo University, p 145

10. Lamizana B (2013), Plastic planet: how tiny plastic particles are polluting our soil, un environment program, ecosystems and biodiversity, available via: https://www.unenvironment.org/news-and-stories/story/plastic-planet-how-tiny-plastic-pa rticles-are-polluting-our-soil. Accessed 1 Mar 2021

11. Ogola JS, Chimuka L, Tshivhase S (2011) Management of municipal solid wastes: a case study in Limpopo province, South Africa. In: Kumar S (ed) Integrated waste management, vol 1. InTech, Rijeka, pp 91-112

12. Banik S (2018) Small scale industries in India: opportunities and challenges. IJCRT $(6,1): 337$ Available via: https://www. researchgate.net/publication/323756073_small_scale_industries_in_india_opportunities_and_challenges. Accessed 1 Mar 2021

13. United Nations (2019) The sustainable development goals report. Department of economic and social affairs, p 45 Available via: https://unstats.un.org/sdgs/report/2019/The-Sustainable-Development-Goals-Report-2019.pdf. Accessed 1 Mar 2021

14. The World Bank (2018), What a waste: an updated look into the future of solid waste management, online article, the world bank, IBRD.IDA, available via: https://www.worldbank.org/en/news/immersive-story/2018/09/20/what-a-waste-anupdated-look-into-the-future-of-solid-waste-management. Accessed 1 Mar 2021

15. Kristanto GA, Koven W (2019) Estimating greenhouse gas emissions from municipal solid waste management in Depok, Indonesia. City Environ Interact 4:1 Available via: https://www.sciencedirect.com/science/article/pii/S25902520203 00088\#bb0030. Accessed 1 Mar 2021

16. Kaza S, Yao L C, Bhada-Tata P, Van Woerden F (2018), What a waste 2.0: a global snapshot of solid waste management to 2050, published book, urban development;. Washington, DC: World bank, P.xi., available via: https://www.worldbank. org/en/news/immersive-story/2018/09/20/what-a-waste-an-updated-look-into-the-future-of-solid-waste-management. Accessed 1 Mar 2021 
17. Abalansa S, El Mahrad B, Vondolia G K, Icely J, Newton A (2020), The marine plastic litter issue: a socialeconomic analysis. Sustainability 2020, 12, 8677. Available via: https://doi.org/10.3390/su12208677. Accessed 1 Mar 2021

18. World Bank (2018) Atlas of sustainable development goals 2018: world development indicators. World bank, Washington, DC. https://doi.org/10.1596/978-1-4648-1250-7 License: Creative Commons Attri-bution CC BY 3.0 IGO, P.7076.https:/olc.worldbank.org/system/files/Atlas\%20of\%20Sustainable\%20Development\%20Goals\%20-\%20Introduction.pdf. Accessed 1 Mar 2021

\section{Publisher's Note}

Springer Nature remains neutral with regard to jurisdictional claims in published maps and institutional affiliations.

Submit your manuscript to a SpringerOpen ${ }^{\circ}$ journal and benefit from:

- Convenient online submission

- Rigorous peer review

- Open access: articles freely available online

- High visibility within the field

- Retaining the copyright to your article 